\title{
TRACING THE DIAGENETIC ORIGIN OF NEOPROTEROZOIC 26-ALKYLSTERANES
}

\author{
L. M. van Maldegem ${ }^{1,2,3}$, B. J. Nettersheim ${ }^{1,2}$, A. Leider ${ }^{1,2}$, J. J. Brocks ${ }^{4}$ and C. Hallmann ${ }^{1,2}$ \\ ${ }^{1}$ Max Planck Institute for Biogeochemistry, Germany; ${ }^{2}$ MARUM - Center for Marine \\ Environmental Sciences, Germany; ${ }^{3}$ Present address: ${ }^{4}$ The Australian National University, \\ Australia.
}

Timing, conditions and triggers surrounding the rise of complex life remain amongst the most highly debated topics in geobiology. In the absence of large body fossils, prior to emergence of the Ediacara biota, molecular biomarkers are our only means to reconstruct the composition of communities during the Neoproterozoic (Brocks et al., 2017; Hoshino et al., 2017; van Maldegem et al., 2019). Recently, novel steranes with a methylation at position C-26 were described to be present in several Neoproterozoic sedimentary rocks (Brocks et al., 2015; Zumberge et al., 2018). These molecules were suggested to derive from sponges, thereby possibly representing the oldest evidence for animals in the geological record (Zumberge et al., 2018). While most recently, one of these purported sponge markers, 26-methylstigmastane, has also been observed in modern Rhizaria (Nettersheim et al., 2019), biological precursors of the $\mathrm{C}_{28}$ steroid Cryostane have not yet been detected in extant organisms.

We found elevated abundances of 26-alkylsteranes in two Neoproterozoic sedimentary sequences. Apart from cryostane, methylated at position C-26, we also detect a pseudohomologous series with C-26-alkylation extending up to $\mathrm{C}_{7}$ in both investigated sample sets. Alongside these 26 -alkylsteranes, the samples also contain abundant $3 \beta$-alkylsteranes. When quantifying the relative abundance of each alkylated molecule $\left(\mathrm{C}_{1}-\mathrm{C}_{7}\right)$ for both $3 \beta$ - and 26-alkylsteranes a significant correlation $\left(\mathrm{R}^{2}=0.98\right)$ is observed between the different homologous series samples with abundances that rapidly decrease with each additional methyl addition. This suggests that these alkylsteranes were generated through similar mechanisms.

Thirty years after their discovery (Summons and Capon, 1988), the formation mechanisms of $3 \beta$-alkylsteranes still remain enigmatic. Once thought to possibly represent membrane lipids of unknown bacteria that modify eukaryotic steroids by adding sugars to the C-3 position (Dahl al., 1992; 1995), they are usually attributed to bacterially mediated processes during diagenesis. Pyrolysis experiments with various sterols have now revealed that alkyl-steranes readily form through diagenetic processes without biology and that the alkylation position is indeed a function of hydroxyl functionalization. Our data suggest that neither 3 $\beta$ - nor 26-alkylsteranes derive from specific alkylated precursors, negating cryostane as a metazoan marker. More importantly, our findings suggest that extended alkylsteranes allow the reconstruction of past side-chain functionalization in ancient steroids, which may open a new realm of biological diagnosticity.

\section{References}

Brocks, J. J., et al. "Early sponges and toxic protists: possible sources of cryostane, an age diagnostic biomarker antedating Sturtian Snowball Earth." Geobiology 14.2 (2016): 129-14

Brocks, J. J., et al. "The rise of algae in Cryogenian oceans and the emergence of animals." Nature 548 (2017): 578.

Dahl, J., et al. "A new class of natural products revealed by $3 \beta$-alkyl steranes in petroleum." Nature 355.6356 (1992): 154. 
Dahl, J., et al. "Extended 3 $\beta$-alkyl steranes and 3-alkyl triaromatic steroids in crude oils and rock extracts." Geochimica et Cosmochimica Acta 59.18 (1995): 3717-3729.

Hoshino, Y., et al. "Cryogenian evolution of stigmasteroid biosynthesis." Science advances 3.9 (2017): e1700887.

van Maldegem, L. M., et al. "Bisnorgammacerane traces predatory pressure and the persistent rise of algae after Snowball Earth" Nature Communications 10 (2019) 1-11.

Nettersheim, B. J., et al. "Putative sponge biomarkers in unicellular Rhizaria question an early rise of animals" Nature ecology \& evolution (2019). In press

Summons, R. E., and R. J. Capon. "Fossil steranes with unprecedented methylation in ringA." Geochimica et Cosmochimica Acta 52.11 (1988): 2733-2736.

Zumberge, J. A., et al. "Demosponge steroid biomarker 26-methylstigmastane provides evidence for Neoproterozoic animals." Nature ecology \& evolution 2.11 (2018): 1709. 